\title{
The Contribution of Vo2 Max and Agility to Dribbling Ability of Football Extracurricular at SMK Forestry Pekanbaru
}

\author{
D Ariyanto \\ Faculty of Psychology, Universitas Negeri Padang, Prof. Dr. Hamka, Padang, Indonesia \\ *Corresponding author. Email: dwiariyanto1994@gmail.com
}

\begin{abstract}
Based on the observations of the author when the team conducted official trials and matches ina championship between Pekanbaru secondary schools, and LPI (Indonesian Education League), it was seen that students' dribbling were troublesome. The purpose of this study was to determine the contribution of VO2 max and agility toward football dribbling skills at Pekanbaru Forestry Vocational High School.

Population in the study was all students (male) enrolledin football extracurricular (17 people). The sample in this study was less than one hundred thus the sample was taken through total samplingtechnique. Based on the results of the research, it can be summarized as follows: there is a relationship between agility and dribbling skills, where rtab at a significant level $\alpha(0.05)=0.497$ means $\mathrm{r}$ count $(0.736)>\mathrm{rtab}(0.497)$ with contributions $54.24 \%$ with the Medium category. Then there is a relationship between endurance (VO2 Max) with dribbling skills, where rtab at a significant level $\alpha(0.05)=0.497$, means $r$ count $(0.560)>r t a b(0.497)$ with a contribution of $31.31 \%$ with the Less category , and there is a joint relationship between agility and endurance VO2 Max with dribbling skills of students of Pekanbaru Forestry Vocational School, where the household at a significant level $\alpha(0.05)=0.497$, means Rhitung $(0.796)>\mathrm{rtab}(0.497)$, with a contribution of $63.36 \%$ in the Good category.
\end{abstract}

Keywords: Vo2 Max, dribbling, football extracurricular

\section{INTRODUCTION}

Sports are part of human daily activities that are useful in forming a healthy body and spirit, until now the sport has provided a positive and tangible contribution to improving public health, besides sports as well play a role in enhancing the nation's ability to implement a sustainable development system, while other benefits of sports in addition to maintaining health are for sports achievements and recreation. Sports achievements in Indonesia are growing along with the desire of the Indonesian people to advance in the field of sports (Ihsan, 2018). Recreational sports are sports that aim to entertain the community, because in recreational sports there is no element of pressure. The Indonesian government also aggressively promotes recreational sports by holding traditional game competitions.

In connection with this matter the government issued law No. 3 of 2005 concerning the national sports system of achievement sports is a sport that fosters and develops sportsmen in a planned, tiered, and sustainable manner through competition to achieve achievements with the support of sports science and technology, achievement sports are obtained by careful preparation, to achieve a satisfying end.

Speaking of sports, of course football is one of the sports games that are currently very popular in Indonesian society. This is due to the large number of competitions or leagues, both inter-Club, School, Student, National and International, ranging from early age to adulthood all competed, carried out by community organizations, students and parent organizations of each competition that is.

To be able to play football, a player must master the techniques in football. According to SukmaAji (2016) "the basic technique of football must be mastered by someone. If someone does a football game, he must know and be able to do the basic techniques or basic movements of the game of football "an athlete must know the various techniques that exist in football, among others: shooting techniques, headingtechniques, dribbling techniques,passingtechniques, controltechniques, technique throw-in technique catch for the keeper. Oriented on a variety of basic football techniques, "dribbling is defined as possession of the ball with the feet while moving on the playing field". 
To defend the ball when running across your opponent or advance to open space, when doingtechniques it isdribblingdivided into several forms of movement, based on the foot's exposure to the ball.

Players must have goodskills on dribblingso they can pass more than one opposing player. Theprocess is dribbling carried out from the opponent's own defense, so that a footballer must have agility and flexibility as well as good possession, in line with that the footballer is required to have a good $\mathrm{VO}_{2} \max$ so as not to get tired quickly when competing, because dribbling is very requires a good $\mathrm{VO}_{2} \max$ so all three of these are very related in the game of football.

Based on the observations of the author when the team conducted an official trial and match, the championship between Pekanbaru high schools, and the LPI (Indonesian Education League) matches many students lacked in dribbling, the ball was often released and easily captured or captured by the opposing party, mastery the ball at dribbling is not so long because $\mathrm{VO}_{2}$ max that students have is not good. The lack of dribbling ability and $\mathrm{VO}_{2} \max$ on the Forestry Vocational School football team makes it difficult for players to set the tempo of the game. Therefore, the authors are interested in drawing a title, $\mathrm{VO}_{2} \max$ and Agility Towards Ability Dribbling Football Extracurricular in Pekanbaru Forestry Vocational School.

\section{METHOD}

This study took place on the football field in Pekanbaru Forestry Vocational School. The time of the study was carried out in September-November 2017. This type of research is a type of correlational research by linking the results of the measurement of two different variables in order to determine the level of relations between these variables (Arikunto, 2006). As the independent variable $\mathrm{VO}_{2} \max (\mathrm{x} 1)$ and agility (x2) while the dependent variable (Y) is dribbling. Population is the whole subject of research (Arikunto, 2006) population in research of all students (female) extracurricular football Pekanbaru State Forestry Vocational School, in this study were the exrakulikuler team of Pekanbaru Forestry Vocational High School amounting to 17 people.

According to Arikunto (2006) the sample is partially or representative of the population studied. Considering the population is less than 100 people, the entire population was taken as sample (total sampling), which is 17 people. This is in accordance with Arikunto (2006) if the number of subjects is less than 100 people, it is better to take all of them, so the research is population research. Therefore the sample in this study is less than one hundred, the sample is taken (total sampling) or the full sampling technique of students (male) extracurricular Pekanbaru State Forestry Vocational High School, amounting to 17 people. The instruments in this study were tests including: $\mathrm{VO}_{2} \max$ test using Bleeb test, Agility Test using Dogging Runandtest Dribbling with dribbling.

\subsection{Data Analysis Techniques}

\subsubsection{Normality Test Data}

Normality of data was tested through using liliefors to find out the data are normally distributed or not, the data connected is linear pattern and the data that is connected has the same pair.

The Lilliefors method uses basic data that has not been processed in the frequency distribution table. Data is transformed in $\mathrm{Z}$ value to calculate the area of a normal curve as a normal cumulative probability. This probability is searched for by the difference between the probability of empirical communication.

\section{Correlation}

The correlation analysis technique used is the Product Moment Correlation proposed by Pearson in Sugiyono (2009). This technique includes parametric statistical techniques that use interval data and ratios with certain requirements.

\section{RESULTS AND DISCUSSION}

Data Description

Durability (VO2 Max)

Power Measurement resistant (VO2 Max) was performed with a bleep test on 17 samples, obtained the best score was 42.10 , the lowest score was 24.65 , mean (34.83), standard deviation 5.63, from the data the results of this test can be made the frequency distribution table as follows:

Table 2. Variable Frequency Distribution of Durability (VO 2 Max)

\begin{tabular}{|c|c|c|c|}
\hline No & Class interval & $\begin{array}{c}\text { absolute } \\
\text { frequency } \\
(\mathrm{Fa})\end{array}$ & $\begin{array}{c}\text { relative } \\
\text { frequency }\end{array}$ \\
\hline 1 & $24,65-28,13$ & 3 & 17,65 \\
\hline 2 & $28,14-31,62$ & 2 & 11,76 \\
\hline 3 & $31,63-35,11$ & 3 & 17,65 \\
\hline 4 & $35,12-38,60$ & 4 & 23,53 \\
\hline 5 & $38,61-42,10$ & 5 & 2941 \\
\hline & & 17 & $100 \%$ \\
\hline
\end{tabular}

Based on the above frequency distribution table from 17 samples, it turns out that 3 samples (17.65\%) had 
results durability with a range of values of 24.65-38.13 in the category less once, then there are 2 samples $(11.76 \%)$ that have endurance results (VO2 Max) with a range of values 28.14-31.62 with Less categories, then 3 samples $(17.65 \%)$ had endurance results (VO2 Max) with a range of values of $31.65-35.11$ in the medium category, then 4 samples $(23.53 \%)$ had endurance results (VO2 Max) with a range of 35.1238.60 with good categories, while 5 samples $(29.41 \%)$ had endurance results (VO2 Max) with a range of values 38.61-42.10 with excellent categories.

Agility

Measurement of agility was carried out bytestdodging run on 17 samples, the fastest score was 6.31 seconds, score was 9.96 seconds late, average (mean) 7.78 seconds, standard deviation 107, from the data of this test results can be made the frequency distribution table as follows:

Table 3. Distribution of Frequency Variables Agility $\left(\mathrm{X}_{1}\right)$

\begin{tabular}{|c|c|c|c|}
\hline No & $\begin{array}{c}\text { Interval Class } \\
\text { Absolute }\end{array}$ & $\begin{array}{c}\text { frequency } \\
(\mathrm{Fa})\end{array}$ & $\begin{array}{c}\text { Relative frequency } \\
(\mathrm{Fr})\end{array}$ \\
\hline 1 & $6.31-7.03$ & 3 & 17.65 \\
\hline 2 & $7.04-7.76$ & 8 & 47.06 \\
\hline 3 & $7.77-8.49$ & 2 & 11.76 \\
\hline 4 & $8.50-9.22$ & 1 & 5.88 \\
\hline 5 & $9.23-9.96$ & 3 & 17.65 \\
\hline & & 17 & $100 \%$ \\
\hline
\end{tabular}

Based on the frequency distribution above from 17 samples, it turns out that there were 3 samples (17.65\%) has the results of agility with a range of values from 6.31 to 7.03 with very little category, then there are 8 sample people $(47.06 \%)$ who have agility results with a range of values from 7.04 to 7.76 with less categories, then there are 2 people the sample $(11.76 \%)$ had the results of agility with a range of values from 7.77 to 8.49 with the medium category, and 1 sample person $(5.88 \%)$ had the results of agility with a range of values from 8.50-9.22 with good categories, and 3 samples $(17.65 \%)$ have agility results with a range of values from 9.23-9.96 with excellent categories.

\section{Ball Dribbling Skill}

Measuring dribbling skills is done by using stop wacth on 17 samples, the fastest score is 17.87 seconds, the slowest score is 22.50 seconds, the average (mean) is 20, 06 seconds, standard deviation 1.19, from the data of this test results, it can be made the frequency distribution table as follows:
Table 4. Distribution of Variable Frequency Ball Dribbling Skills (Y).

\begin{tabular}{|c|c|c|c|}
\hline No & $\begin{array}{c}\text { Interval Class } \\
\text { Absolute }\end{array}$ & $\begin{array}{c}\text { Frequency } \\
(\mathrm{Fa})\end{array}$ & $\begin{array}{c}\text { Relative } \\
\text { Frequency (Fr }\end{array}$ \\
\hline 1 & $17,87-18,79$ & 3 & 17,65 \\
\hline 2 & $18,80-19,72$ & 3 & 17,65 \\
\hline 3 & $19,73-20,65$ & 6 & 35,29 \\
\hline 4 & $20,66-21,58$ & 4 & 23,53 \\
\hline 5 & $21,59-22,51$ & 1 & 11,76 \\
\hline & & 17 & $100 \%$ \\
\hline
\end{tabular}

Based on the above frequency distribution table from 17 samples, it turns out that 3 samples (17.65\%) had dribbling skills with a range of values of 17.8718.79 with a very good category, then 3 samples $(17.65 \%)$ have the results of dribbling skills with a range of values 18.80-19.72 with good categories, then 6 samples $(35.29 \%)$ have the results of dribbling skills with a range of values of 19.73-20.65 with a moderate category, while 4 samples $(23.53 \%)$ have dribbling skills with a range of values of $20.66-21.58$ with less categories, and 1 sample person $(11.76 \%)$ has the results of dribbling skills with a range of values 21.5922.51 with very few categories.

Testing Requirements Analysis

The test was carried out by lilliefors test. The results of the normality test analysis of each variable are presented in the form of the table below.

Table 5. Test for normality of the data by lilliefors test.

\begin{tabular}{|c|c|c|c|c|}
\hline No & Variable & Lo & Lt & Description \\
\hline 1 & Agility & 0.085 & 0.206 & Normal \\
\hline 2 & $\begin{array}{c}\text { Durability } \\
\text { (VO2 Max) }\end{array}$ & 0.134 & 0.206 & Normal \\
\hline 3 & Dribbling & 0.117 & 0.206 & Normal \\
\hline
\end{tabular}

In the table above, it can be seen that the results Lo variable dribbling skills, agility and Durability (VO2 Max) smaller than Lt, it can be concluded that the data is normally distributed.

The results of the calculation of a simple correlation coefficient can be seen as follows: 1) Calculation of the correlation coefficient value of $\mathrm{X}_{1}$ to $\mathrm{Y}$ is 0.736 ; 2) The calculated coefficient of correlation value $\mathrm{X}_{2}$ to $\mathrm{Y}$ is 0.560

Testing of Hypotheses

Testing of Hypothesis Two

Testing of the first hypothesis is that there is a relationship between agility and the results of dribbling skills. Based on the analysis carried out, the average dribbling skills obtained were 20.06 seconds with a 
standard deviation of 1.19 . For the average score of Durability (VO2 Max) obtained 34.83 seconds with a standard deviation of 5.63. From the information above,

we obtained a correlation analysis between Durability (VO2 Max) and dribbling skills, where $\mathrm{r}_{\mathrm{tab}}$ at a significant level $\alpha(0.05)=0.497$ means $r_{\text {count }}(0.560)>r_{\text {tab }}(0.497)$, meaning the hypothesis is accepted and there is a meaningful relationship between agility and student dribbling skills. Extracurricular PekanbaruPekanbaru Forestry Vocational School. It can be seen in the table below:

Table 6. Interrelation Correlation Analysis (VO2 Max) With Ball Herding Skills $\left(\mathrm{X}_{2}-\mathrm{Y}\right)$.

\begin{tabular}{|c|c|c|c|}
\hline $\mathrm{dk}(\mathrm{N}-1)$ & $\mathrm{r}_{\text {count }}$ & $\begin{array}{c}\mathrm{r}_{\text {table }} \\
\alpha=0.05\end{array}$ & Conclusion \\
\hline 16 & 0.560 & 0.497 & $\begin{array}{c}\mathrm{Ha} \\
\text { accepted }\end{array}$ \\
\hline
\end{tabular}

Note: $\mathrm{dk}=$ degree of freedom

The results of the correlation analysis state that there is a significant relationship between Endurance (VO2 Max) and dribbling g skills at a significant level of $\alpha=0.05$.

Testing Hypothesis One

Testing of the first hypothesis is that there is a relationship between agility and dribbling skills. Based on the analysis carried out, it was obtained that the average dribbling skill was 20.06 seconds, with a standard deviation of 1.19 . For the average score of agility was 7.78 seconds with a standard deviation of 1.07. From the information above, we obtain a correlation analysis between agility and dribbling skills, where $r_{\text {tab }}$ at the significant level $\alpha(0.05)=0.497$ means $r_{\text {hutung }}(0.736)>r_{\text {tab }}(0.497)$, meaning the hypothesis is accepted and there is a meaningful relationship between agility towards dribbling skillsExtracurricular students of Pekanbaru Forestry Vocational School. To more clearly it can be seen in the table below:

Table 7. Correlation Analysis Between Agility With Ball Dribbling Skills $\left(\mathrm{X}_{\mathrm{l}}-\mathrm{Y}\right)$.

Note: $\mathrm{dk}=$ degrees of freedom

\begin{tabular}{|c|c|c|c|}
\hline $\mathrm{dk}(\mathrm{N}-1)$ & rcount & $\begin{array}{c}\text { rtable } \\
\alpha=0: 05\end{array}$ & Conclusion \\
\hline 16 & 0.736 & 0.497 & $\begin{array}{c}\text { Ha } \\
\text { received }\end{array}$ \\
\hline
\end{tabular}

The results of the correlation analysis state that there is a significant relationship between agility and dribbling skills at a significant level of $\alpha=0.05$.

Testing Hypothesis Three

Testing the third hypothesis is that there is a relationship between agility and endurance (VO2 Max) with dribbling skills. Based on the analysis carried out, the correlation analysis between agility and durability was obtained (VO2 Max) on dribbling skills as follows:

Table 8. Correlation Analysis Between Agility and Durability $\left(\mathrm{VO}_{2} \mathrm{Max}\right)$ with Ball Dribbling Skills $\left(\mathrm{X}_{1}\right.$, $\left.\mathrm{X}_{2-} \mathrm{Y}\right)$

\begin{tabular}{|c|c|c|c|}
\hline $\mathrm{dk}(\mathrm{N}-1)$ & $\mathrm{R}_{\text {count }}$ & $\begin{array}{c}\mathrm{R}_{\text {table }} \\
\alpha=0.05\end{array}$ & Conclusion \\
\hline 16 & 0.796 & 0.497 & $\begin{array}{c}\text { Ha } \\
\text { accepted }\end{array}$ \\
\hline
\end{tabular}

Note: $\mathrm{dk}=$ degree of freedom

The results of the correlation analysis state that there is a significant relationship between agility and endurance (VO2 Max ) with dribbling skills at a significant level of $\alpha=0.05$.

Discussion

Contribution of Endurance (VO2 Max) withBall Skill

Durability (VO2 Max) plays an important role in every branch, including the football branch. Even Endurance (VO2 Max) is a very good element in determining the success of dribbling. On the other hand Endurance (VO2 Max) also greatly determines the quality of one's dribbling movements. If endurance is good, then a player will be easy to control the ball, and vice versa.

From the results of the analysis that has been found, it can be concluded that there is a significant relationship between the flexibility with students' dribbling skills. Extracurricular Pekanbaru National Vocational High School, Endurance Level (VO2 Max) that athletes have would be better if they did not ignore the factors that affect dribbling skills.

Not much different from agility, endurance (VO2 Max) also influences athletes' dribbling skills. Based on the results of the analysis of the collected data, it also states that there is a relationship, meaning that the increase that occurs from the athlete's dribbling is influenced by the endurance (VO2 Max) of the athlete.

The results of the contribution given by endurance to dribbling skills are equal to $31.31 \%$. This means that there are $31.31 \%$ endurance affecting herding skills. Both endurance and good dribbling skills students Extracurricular Vocational School of Forestry Pekanbaru 
Agility Contributions with Ball Dribbling Skills

In football games agility conditions are needed to control the ball, dribble the ball, pass the opponent and turn around in a short time to overcome the spoils of the ball from the opponent. Football students who have good agility tend to have smooth movement coordination, because coordination is a collaboration between the central nervous system and the muscles used in making movements. In football games there will be a good coordination of movement, if a student can move towards the ball that comes while making a move to hold the ball, kick and change direction according to the desire when playing.

From the analysis that has been found it can be concluded that there is a significant relationship between agility with dribbling skills Extracurricular student of SMK NegeriForestryPekanbaru.The level of agility possessed by athletes will certainly be better if they do not ignore the factors that can affect dribbling skills.

The results of the contribution given by agility to dribbling skills are equal to $54.24 \%$. This means that there is $54.24 \%$ of agility affecting herding skills. Good agility is also good students dribbling skills Extracurricular Pekanbaru Forestry Vocational School.

Agility and Durability Contributions (VO2 Max) with Ball Herding Skill Results

One technique that is needed in football games is the technique of herding or dribbling a ball. Dribbleis one of the important technical parts to achieve an achievement, when dribbling players are required to master the ball in various positions with all parts of the body except the hands, the movement of dribbling is done very quickly because the player has limited time and space. Soedjono (1985) Further explained dribblingis carrying the ball with the foot with the aim of passing the opponent, next to the goal to dribblealso useful for finding opportunities to give feedback to friends (AangWitarsa, 1979)

Some factors that greatly determine the dribbling skills of the ball are Durability (VO2 Max), endurance, agility, flexibility, movement coordination, student mentality, training program, infrastructure. From the results of the analysis that has been found, it can be concluded that there is a significant relationship between agility and endurance (VO2 Max) with dribbling skillsstudents from PekanbaruForestry Vocational School

For example,Fitrah, for example, lead to maximum time together with good endurance and good agility. But there are also those who are less like Azhar, poor agility, getting good results.

It was different from M. Azim who dribbled a ball that was not good enough, lacked agility but had a pretty good endurance. Likewise with Syafatul, who has good endurance but the results of pushing the ball are not good. Some of the results seen above can be concluded by researchers that of the few players who have good agility, good herding skills and good endurance, there are also those that only have good endurance but others are not good.

This means that all that can improve dribbling skills, such as agility and endurance (VO2 Max). However, researchers only connect to these two forms of physical condition. Actually there are still many who can increase the ability to dribble like flexibility.

The contribution results provided by agility with endurance to dribbling skills are equal to $63.36 \%$. This means that there is $63.36 \%$ agility with durability affecting herding skills. Both agility and endurance are also good students dribbling skills Extracurricular Pekanbaru Forestry Vocational School.

\section{CONCLUSION}

Based on the author's observation when the team conducted official trials and matches, the championship between Pekanbaru high schools and LPI (Indonesian Education League) matches many students were lacking in dribbling, the ball was often released and easily captured or captured by the opposing parties, possession during dribbling is not so long because $\mathrm{VO}_{2}$ max that students have is not good. The population in the research of all students (male) of extracurricular football in the Pekanbaru Forestry Vocational School, amounting to 17 people. The sample in this study was less than one hundreds, the sample was taken (total sampling) or the full sampling technique of students (sons) extracurricular Pekanbaru Forestry Vocational High School amounting to 17 people.

Based on the results of the research that the author has described in the previous chapter, it can be concluded as follows: there is a relationship between Endurance (VO2 Max) with dribbling skills, where $r_{\text {tab }}$ at significant level $\alpha(0.05)=0.497$, means $\mathrm{r}_{\text {count }}(0.560)>\mathrm{r}_{\mathrm{tab}}(0.497)$ with a contribution of $31.31 \%$ with Less category, ThenThere is a relationship between agility and dribbling skills, where $r_{\mathrm{tab}}$ at the significant level $\alpha(0.05)=0.497$ means $r_{\text {count }}(0.736)>r_{\text {tab }}(0.497)$. With a contribution of $54.24 \%$ with the Medium category, and there is a joint relationship between agility and endurance (VO2 Max) with students dribbling skills Extracurricular Pekanbaru Forestry Vocational High School, where $r_{\text {tab }}$ at significant level $\alpha$ $(0.05)=0.497$, means $\mathrm{R}_{\text {count }}(0.796)>\mathrm{r}_{\mathrm{tab}}(0.497)$, with a contribution of $63.36 \%$ in the Good category. 


\section{REFERENCES}

[1] Arsil. 1999. Pembinaankondisifisik. Padang: FIK UNP.

[2] Arikunto, Suharsimi (2002). Prosedur penelitian suatu pendekatan praktek: Jakarta. PT Renika Cipta.

[3] A. Sarumpaet. 1992. Permainan besar. Padang : Depdikbud

[4] Baley, James a. 1986. Pedoman Atlet Teknik Peningkatan Ketangkasan Dan Stamina.Semarang : Bahasa Prise

[5] Bompa, Tudor O. 1983. Theory and methodology of training.Dubuge : Kendall/Hunt Publishing Company

[6] Csanadi Arpad. 1972. Football. Budapest :Corvina Press

[7] Darwis, Ratinus. 1999. Sepakbola. Padang : FIK UNP.

[8] Djezet, Zulfar. 1984. Bukupengajaransepakbola. Padang : FPOK IKIP.

[9] Dinas Pendidikan Nasional. 1999. Pengukuran Kesegaran Jasmani, Jakarta.

[10] Dangsina Moeloek, Arjadino Tjokro. 1984. Kesehatan dan olahraga. Jakarta :

[11] Engkos Kosasih. 1985. Olahraga Teknik Dan Program Latihan. Jakarta: Akademika presindo.

[12] Harsono. 1988. Coaching dan Aspek-Aspek Psikologi Dalam Coaching. Jakarta : PT. Dirjen DIKTI P2LPT

[13] Harsuki, 2003. Perkembangan Olahraga Terkini, Jakarta : Pt Rajagrafindo Persada Jossef N. 1982. General Theory Of training.Lagos : Pan African Press LTD

[14] Lutan, Rusli. 1988. Belajar ketrampilan Motorik Pengatar Teori Dan Metode. Jakarta : P2LPTK DIRJEN DIKTI DEPDIKBUD

[15] Luxbacher, Joe. 2012.Sepakbola.TaktikdanTeknikBermain.PT RajagrafindoPersada. Jakarta

[16] Mielke, Danny. 2007. Dasar-dasar sepakbola. Pakaraya : Bandung

[17] Nurhasan. 2001. TesdanPengukuranDalamPendidikanJasmaniPrin sip-prinsipdanpenerapannya.

Jakarta Pusat.DirektoratJendralOlahraga.

[18] N Ihsan, S Suwirman. 2018. Sumbangan Konsentrasi terhadap Kecepatan Tendangan Pencak Silat. Media Ilmu Keolahragaan Indonesia 8 (1)

[19] Poerwono, UNP. 2007/2010.PedomanPanduanPenulisanSkripsi. Padang

[20] PSSI. 2007/2008. Peraturan Permainan Sepakbola. Jakarta.
[21] Soekatamsi. 1992. Permainan Bola Besar 1 (Sepakbola). Jakarta : DIRJEN DIKTI, Proyek Pembinaan Tenaga Pendidikan.

[22] Sajoto. 1995. Pembinaan Kondisi Fisik Olahraga. Jakarta : DEPDIKBUD DIRJEN DIKTI PPLPTK

[23] Soejono. 1985. Sepakbola: Taktik Dan Kerjasama. Yogyakarta: PT. Badan Penerbit Kedaulatan Rakyat

[24] Sudjana. 1992. Teknik Regresi Dan Korelasi. Bandung: Tarsito

[25] Suharno HP.1985. Ilmu kepelatihan olahraga. Yogyakarta.1978. Ilmu coaching umum. Yogyakarta :Yayasan STO

[26] Syafruddin. 1999. Pengantar Ilmu Melatih. Dip. Proyek UNP Dasar-Dasar Kepelatihan Olahraga. Padang FIK UNP.

[27] UU no. 3.2005. Tentang Sistim Keolahragaan Nasional. Jakarta: DEPDIKBUD 